\title{
Effect of Rational Advertisement Appeal on Online Branding in Pakistan
}

\author{
Muhammad Shoukat Malik \\ Director, Institute of Banking and Finance \\ Bahauddin Zakariya University, Multan, Pakistan \\ E-mail: shoukatmalik@bzu.edu.pk
}

Rabia Tanveer

MS (Business Administration) Scholar, Institute of Banking and Finance

Bahauddin Zakariya University, Multan, Pakistan

E-mail: Rabia_tanveer77@yahoo.com

Received: September 11, 2018 Accepted: October 22, 2018 Published: November 23, 2018

doi:10.5296/ijim.v3i1.13635 URL: https://doi.org/10.5296/ijim.v3i1.13635

\begin{abstract}
The purpose of this study is to identify the effect of rational advertisement appeal on online branding within the context of Pakistan. Customer attitude is the moderator. The relationship between attitude of customers and online branding is also taken into consideration. Personal items and gadgets are two types of products considered in order to determine differences in purchases while being online. A quantitative survey based research design is used in this study. Nonprobability sampling technique of convenience sampling is used. Data were collected through an online questionnaire. 244 usable responses were obtained. Data was analyzed using SPSS 22. Factor analysis was performed followed by regression analysis and T-test. Results of data analysis revealed that a rational advertisement appeal is a significant predictor of online branding. Customer attitude did not moderate the relationship between rational advertisement appeal and online branding. However, customer attitude had a positive influence on online branding. There were some differences between the product types when consumers purchased online for personal items and gadgets. This study made an important contribution in the literature by investigation the effect of rational advertisement appeal on online branding.
\end{abstract}

Keywords: Rational advertisement appeal, Customer attitude, Online branding, Internet, Online channel, Websites 


\section{Introduction}

In everyday life we come across many advertisements. Nwankwo et al. (2013) said that advertisement is a way of communicating which is targeted towards groups and population. A particular element of an advertisement can be called an appeal when it is able to attract the targeted audience. There are two approaches by which appeals can be incorporated in the advertisement message and these are rational appeals and emotional appeals (Behboudi et al., 2014). In this paper the focus would be on rational advertisement appeal.

Rational advertisement appeal is defined as "Ad execution designed to appeal to the rationality of the receiver by using objective information describing a brand's attributes or benefits" (Yoo \& Maclnnis, 2005, p. 1). Rational advertisement appeals convey the basic functioning and advantages of the product or service (Pang, Keh \& Peng, 2009). Such appeals alter the attitude of the customers receiving the message regarding the product and are based on the power to persuade related to the features of the product. Information, reason and logical arguments are the means by which rational appeals motivate the customers to make right decision (Behboudi et al., 2014).

Customer attitude has a significant importance for the marketers. Attitude formed towards advertising helps in shaping the purchase behavior regarding the brands. Customer attitude is formulated with the help of advertisement.

"Branding has been around for centuries as a means to distinguish the goods of one producer from those of another" (Kotler \& Keller, 2006, p. 310). The difference is based on the rationality, functional aspects or tangibility that is associated with how the brand performs. Branding on the web is increasingly becoming popular and it is done by keeping in view the preferences of the target audience. Online channel favorably affects attitude and purchase behavior in case of all brands. The retailers of the online store can use its features and design elements to influence the behavior of consumers (Urizza \& Cebollada, 2012).

Social media is greatly affecting the marketing communication and it has a significant impact on the consumer decision making process. Customer's favorable attitude shapes their intentions and behavior regarding the products advertised on social media (Abzari et al., 2014). Scolari (2008) is of the view that for the online brands customers are the center of attention with which they have to communicate and manage all their activities accordingly. Customer attitude differs significantly on the internet on the basis of product type (Vijayasarathy, 2002). Lian and Lin (2008) explains the difference in the customer attitude that exists while purchasing different types of products from the online medium. So different product types affect consumer perception and behavior towards their online purchase.

\subsection{Problem Statement}

Internet usage is increasing and people are increasingly affected by this medium. There is a need to identify how rational advertisement appeals affect the attitude of customers and how these appeals make the brands successful on the internet. This study is focused towards online branding so as to identify how people are affected by the brands advertised on the internet. Further it would help in identifying whether there exist any product type differences 
or not, while purchasing from internet. It is valuable to conduct a study on online branding in Pakistan.

\subsection{Research Objectives}

- To determine how rational advertisement appeal makes the brands successful on the internet

- To identify how consumer attitude is affected by this advertisement appeal

- To identify impact of customer attitude on the success of online brands.

- To identify the differences in purchase of product types within the context of online brands.

\subsection{Research Questions}

RQ1: What is the effect of rational advertisement appeal on online branding?

RQ2: What is the role of rational advertisement appeal in formulating customer attitude?

RQ3: What is the impact of customer attitude on online brands?

RQ4: Do product type differences exist while purchasing within the context of online branding?

\subsection{Significance of the Study}

According to "Internet World Stats" (2015), there are 48.2\% internet users in Asia, $18 \%$ in Europe, $10.2 \%$ in Latin America, 9.3\% in North America, 9.8\% in Africa, 3.7\% in Middle East and $0.8 \%$ in Australia on November 30, 2015. Pakistan is the third most populous Muslim country. All these indicate the growing importance and usage of internet. As Pakistan is a Muslim country and internet usage is continuously increasing, it would be interesting to conduct a study on rational advertisement appeal. The effect of using rational advertisement appeal on online branding is new topic of research in Pakistan.

\section{Literature Review}

Advertisement refers to the ways of establishing connection and communication with the masses. Several media types such as audio, visual and print media and the internet media are used for this purpose. Advertisement conveys information in the form of message regarding a particular brand and products that come under its domain (Nwankwo et al., 2013). Appeal in an advertisement conveys the basic meaning behind the advertisement.

\subsection{Rational Advertisement Appeal}

Nwankwo et al. (2013, p. 2) defined rational advertisement appeal as "By rational advertisement appeal, the product can be emphasized to highlight its functions and benefits to the consumer." In rational advertisement appeal products features and advantages are presented to the customer. Rational appeals fulfill the individual's utilitarian needs. These appeals are associated with products that are complex and with business to business 
advertisers. They require great amount of attention and involvement of the customers. Holbrook (1978) says that consumers will have highly favorable beliefs due to the reliability of the facts presented by rational advertisement appeal. Advertisement is used by marketers to compete by acquiring brand new customers and by keeping the customers they already have. Different advertising appeals such as rational and logical are utilized by marketers in order to communicate information to users and for achieving the required goals and objectives of the marketing firm (Wang, Qiu, Kim, \& and Benbasat, 2016).

\subsubsection{Information}

On the online channel rational advertisement appeals are much valuable. Because on the internet, web sites containing the required information that customer want are shaping their purchase intentions (Lwin et al., 2013). Puto and Wells (1984) posit that accurate information regarding brands, services and products serves as the stimulus for rational advertisement appeals. This is due to the fact that this information demands the customer to cognitively evaluate the qualities of the brand, service and the product. According to Meinard and Tsoukiàs (2018), customers that are highly inclined towards reasoning and thinking make an in-depth assessment of the information depicted in advertisements as compared to those that are not much concerned about thorough thinking. For the sake of information sometimes advertisements contain arguments in order to give logic and reasoning to their users

\subsubsection{Factors}

There are certain factors which affect the rational appeal. In terms of advertisement strategies, pull strategies are effective with rational appeals and Muslim customers are more affected by them. For user types, heavy users of a product are more affected by rational appeals as compared to medium and light users. Consumers need more information when they are buying a product which has high level of involvement, so rational appeals are used for them. Among Muslim customers whose lifestyle gives preference to e-shopping, are influenced by rational appeals. As regards of the motive behind using the internet, customers who use internet to look up for information are more influenced by rational appeals (Behboudi et al., 2014).

According to Wagner, Baccarella, and Voigt (2017) the application of appeals varies by the type of product and country. The culture of the country will affect that which appeal should be utilized for the advertisement of a specific product. For advertising across the countries by considering rational and emotional advertisement appeals, product category and culture should be well apprehended. This indicates that the application of rational and emotional appeals for promotion is not only dependent on the culture of a particular country but also on the type of the product

\subsection{Customer Attitude}

Kotler et al. (1999, p. 249) defined attitude as "a person's consistently favorable or unfavorable evaluations, feelings and tendencies towards an object or idea."Spears and Singh (2004, p. 4) defined attitude toward the brand as "attitude toward the brand is a relatively enduring, unidimensional summary evaluation of the brand that presumably energizes 
behavior."

Mitchel and Olson (1981) posits that beliefs regarding the product attributes play an important role in formulating attitude toward the brand and these attitudes in turn has a mediating effect on behavior intentionality. Customers develop attitudes towards the brand because of the features and beliefs that are formulated regarding the brand. But this brand attitude is also affected by the visual appeals depicted in advertisements and customers preferences towards the advertisements.

According to Saadeghvaziri, Dehdashti and Askarabad (2013, p. 11) "product information, social role and image, hedonic/pleasure and irritation are the belief factors" that determine the users attitude regarding online advertisements. Product information helps in formulating a favorable attitude as this is the basic requirement for users to access the internet, hedonic factor refers to the fact that with appealing, entertaining, pleasing and inspiring designs, the respondents' attitudes would be enhanced and social role also influences attitude. These belief factors have an impact on consumers in formulating their attitude. When users have a positive attitude for online advertisements then this will have an important impact on their intention to make a purchase and their resulting behavior.

According to Teo (2002) a thorough understanding of the customer attitude can help the business owners to plan and develop such strategies which can successfully contribute to the buying and selling of products and services over the internet. This is possible because once customer's attitudes are perceived it becomes easier to understand which factors persuade the users to purchase online. In terms of determining the value of the advertisements within the social media, youngsters who are between 19 to 24 years of age prefer information over entertainment. As compared to the male audience, females consider the advertisements displayed on social networking media as offering high entertainment and information (Logan et al., 2012).

Customers preferred to explore the required information before buying which shows they are more alert and vigilant. As this search process assures them that they purchased the best item. This search for information has a significant role in determining their attitude regarding the advertisements on the web. But it is important that customers get the desired value otherwise they will not prefer to buy online (Cheng, Wu, \& Chen, 2018)

Social media advertising is naturally based on the text. And moreover it would be more acceptable for advertisers to involve the consumers in the advertisements advertised on social networking sites by including branded material (Hunt, 2018).

\subsection{Online Branding}

Kotler et al., (1999, p. 571) defined a brand as "A name, term, sign, symbol or design, or a combination of these, intended to identify the goods or services of one seller or group of sellers and to differentiate them from those of competitors."Rowley (2004) says that brands are not created by their design such as their trademark or the physical appearance but instead these things are required to identify the brand and accelerate the whole process of branding. A strong brand makes the customers loyal, delivers the desired quality, creates awareness of its 
name, establish brand connections and is registered (Choo et al., 2012).

Kay (2006) says that branding is a way by which marketers not only give title to their brand but also inform customers about it and differentiate their products from other related products in a well known class of products. Interactivity makes branding successful, which is also a mutual process. Brands make consumers loyal as they are substantial and figurative products having a significant influence on the society. The power of branding process is dependent on its ability to provide reason and rationale. As brands are used to describe the cause behind the significance of products and services to customers. Brands purpose is to generate value (Kay, 2006; Tan \& Rasiah, 2011). Because it represents certain traits, builds relation to develop identity, is valid and represents a favorable image. Meanwhile marketers have to be effective in delivering value of the brand to consumers so as to eliminate any uncertainty (Tan and Rasiah, 2011).

According to de Almeida, Scaraboto, dos Santos Fleck, and Dalmoro (2018) internet is basically used as a means of conveyance, getting facts and enjoyment, although it is also growingly used for conducting business. Marketers use this online channel to market their products. Internet offers goods and services at reasonable prices, and helps both organizations and individuals to establish bilateral association with consumers and sellers

\subsubsection{Steps for Establishing an Online Brand}

According to Bergstrom (2000) branding on the web is a difficult task. Establishing an online brand requires some steps. A first step involves a thorough description of the brand (Jevons, 2005). Second step involves identifying the best setting for the brand which relates to the particular type of business that the company wants to conduct and its target customers. Third step consists of developing a strategy for the brand. Fourth step is about the activities that are required to be done relevant to the brand in the particular business where the brand is operating. Fifth step consists of using the internet as a source of developing emotions and rapport by making use of its unique features such as animations, interactivity and enjoyment (Bergstrom, 2000;, Ko et al., 2005). Finally the sixth step recognizes the fact that brands require change but they should be observed and determined for their ability to serve the customer needs (Bergstrom, 2000).

\subsection{Product Type}

Zhang (2008) is of the view that there is a remarkable influence of the product type on which medium is selected to make the purchase. Such difference may exist for experience and search goods. The product that consumer wants to purchase determines whether to purchase from online channel or to go for the offline stores.

According to Fazal-e-Hasan, Ahmadi, Mortimer, Grimmer, and Kell (2018), various categories of products are available on the internet. This medium is effective in terms of offering the required experience to the users that has more influence than verbally explaining the product features. There exist notable differences among the products on the internet and these differences further segment the customers according to their interest and they are directed to the products of their choice. . Products that are efficiently promoted through this 


\section{Macrothink}

medium have more chances to be purchased online by the audience. Special attention should be given to products that require more information search and those related to computer (Moon \& Sprott, 2016).

Miguel et al. (2015) puts forward the view that there are certain factors that affect the approval and utilization of online channel for purchasing products. Customers who are either males or females both admire the phenomenon of shopping from the internet for different types of products. But several factors vary according to the type of product being considered. These factors relate to the consumer's intention to make the purchase, the risk associated with the product and their existing behavior towards shopping. These factors affect the type of the product being considered and these factors differ in accordance with the product type. Product type differences account for the differences in purchase among the consumers on the online channel. These differences are also prevalent among the people of different age groups who use the internet for shopping (Sorce et al., 2005).

\section{Theoretical Framework}

Rational advertisement appeal is the independent variable whereas online branding is the dependent variable. Customer attitude plays the role of moderator.

\subsection{Research Model}

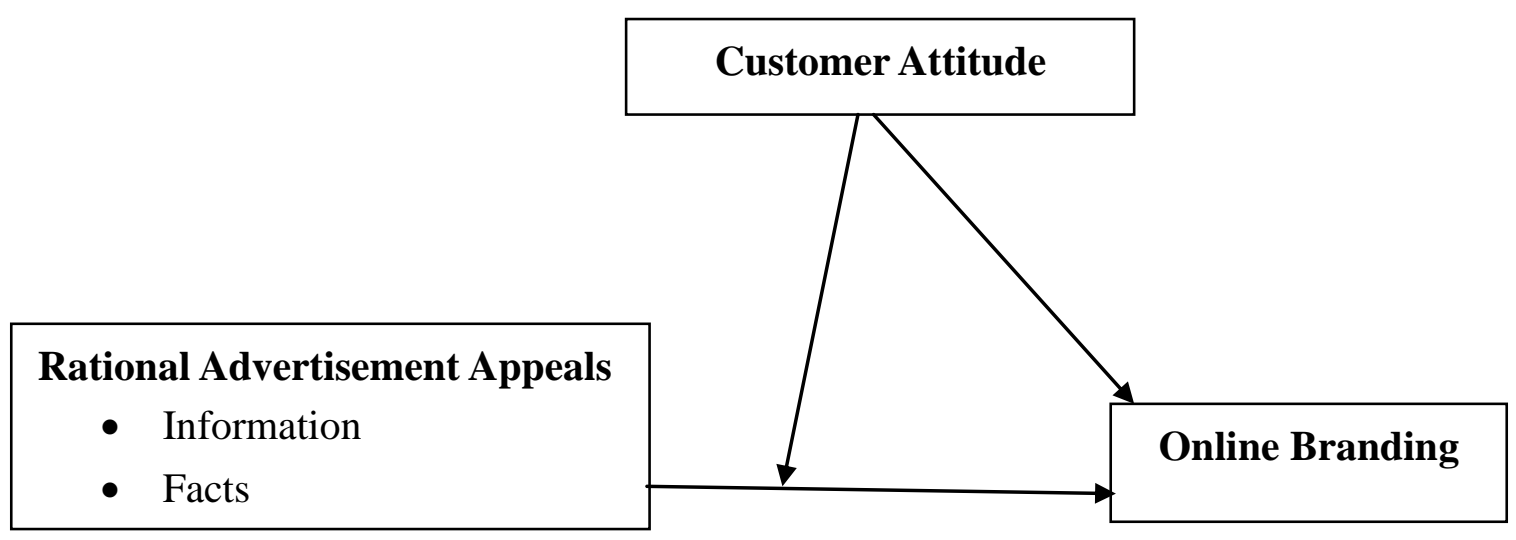

\subsection{Hypothesis}

H1: There is a significant relationship between rational advertisement appeals and online branding.

$\mathrm{H} 2$ : Customer attitude moderates the relationship between rational advertisement appeals and online branding.

H3: There is a positive influence of customer attitude on online branding.

H4: There is a significant difference between purchase of personal items and gadgets with respect to online branding. 


\subsection{Hypothesized Research Model}

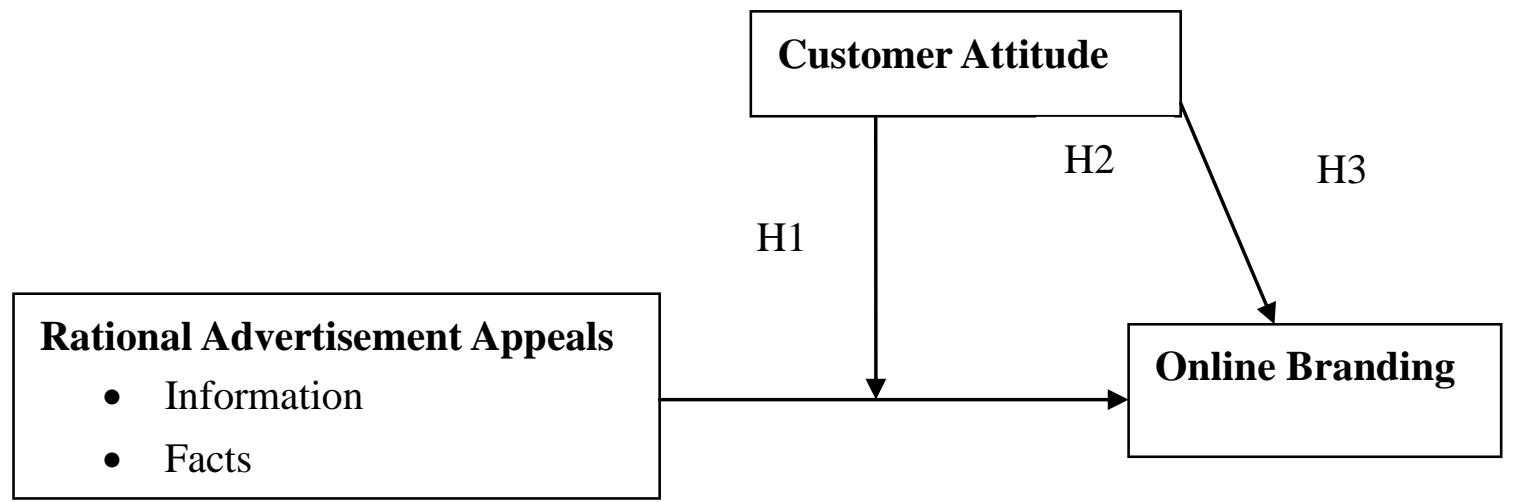

\subsection{Measurement of Variables}

There are four questionnaire statements for rational advertisement appeal which are taken from Verma (2009). Customer attitude is measured with the help of seven statements adopted from Celebi (2015). Online branding is measured with the help of twenty one statements that are adopted from Christodoulides et al. (2006). An open ended question is used in online branding section of the questionnaire which states "what are the recent online purchases you made?" This question is constructed so as to observe the product type differences while purchasing online.

\section{Research Methodology}

\subsection{Research Design}

A quantitative research design is used for this study. "Quantitative research begins with a problem statement and involves the formation of a hypothesis, a literature review, and a quantitative data analysis" (Williams, 2007). Further this is an explanatory research. It determines whether rational advertisement appeal is the cause of success of online branding in Pakistan.

\subsection{Population and Sample}

The population of the study is the users of internet. Among the internet users, the ones who do online shopping constitute the population of this study. Sample size of 244 is used to collect data.

\subsection{Selection of Respondents}

The respondents used for this study are the online shoppers. These respondents are selected using non probability sampling technique of convenience.

\subsection{Methods of Data Collection}

An online questionnaire is developed as a source of primary data collection. Questionnaire was sent to respondents through social media that is facebook. Questionnaire was also posted on several groups on facebook. Some questionnaires were also mailed to respondents to get 
the response. A total of 272 responses were received from which 28 responses were eliminated. These responses were eliminated because these respondents had never done online shopping. 244 usable responses were obtained. The questionnaire had three sections. Section 1: Demographic profile, Section 2: Rational advertisement appeal, Section 2: Customer attitude and Section 3: Online branding.

\subsubsection{Scale}

The demographic profile of the respondents was measured using a nominal scale. While the remaining questions are measured using a 5-point Likert scale where ' 1 ' stands for 'strongly agree' and ' 5 ' for 'strongly disagree'.

\subsection{Methods of Data Analysis}

Data is analyzed using SPSS 22. Data is analyzed in terms of descriptive statistics, factor analysis and regression.

\subsubsection{Factor Analysis}

Factor analysis is performed using principal component analysis as the extraction method. Factor analysis is conducted for this study in order to reduce the data and to determine the items that are the cause of relationship among the variables

\subsubsection{Regression Analysis}

Regression analysis is performed in order to determine any likely and considerable increase in the variances (Kim \& Bonn, 2015) and to identify that customer attitude, which is a moderator, had an effect on online branding.

\subsubsection{T-test}

The T-test used is two independent samples T-test. T-test is conducted here to identify whether there is any significant difference between the purchases of two different product categories within the context of online branding.

\section{Data Analysis}

Data is analyzed using SPSS 22. First a factor analysis is performed. The items that did not load in factor analysis were excluded and the analysis was performed again. 34 of the 41 items loaded on 5 factors. Online branding, which is the dependent variable is treated as two variables, on the basis of factor analysis, which is online branding features and online brand's website elements. Rational appeal accounts for $6.511 \%$ of variance in the model whereas customer attitude holds $10.732 \%$ of the variance in the model. Online branding features account for $28.209 \%$ of the variance and online brand's website elements accounts for $5.304 \%$ of the total variance. Table 1 shows variance of these five factors in total is $50.756 \%$. These factors are causing approximately $51 \%$ variance in the model.

Reliability of the factors is measured with the help of cronbach's alpha. The maximum value for cronbach's alpha at which a factor is supposed to be reliable is 0.7 and above or 0.75 (Christmann \& Aelst, 2006; Kahreh, Shirmohammadi, \& Kahreh, 2014). Rational appeal has 


\section{Ml Macrothink}

Cronbach's alpha value of 0.873 , customer attitude has 0.780 , online branding features and online brand's website elements also show acceptable alpha values of 0.895 and 0.791 respectively. Cronbach's alpha value for all the questions came out to be .912 . So these scale items are reliable.

Table 1. Factor analysis

\begin{tabular}{|l|c|c|}
\hline Variables & \% of Variance & Cronbach's Alpha \\
\hline Online Branding Features/online brands website elements & $28.209 / 5.304$ & $.895 / .791$ \\
\hline Customer Attitude & 10.732 & .780 \\
\hline Rational Appeal & 6.511 & .873 \\
\hline Total & 50.756 & .912 \\
\hline
\end{tabular}

After factor analysis a regression analysis is performed. In Table 2 the first regression has $\mathrm{R}^{2}$ value of 0.053 which is significant. F value for model 1 is 13.642 with level of significance of 0.000 which is less than 0.05 so this $\mathrm{F}$ value is significant. Model 1 gives beta value of .233 which is significant at 0.000 . This indicates that 1 unit standard deviation change in rational appeal can cause .233 units standard deviation change in online branding.

Table 2. Regression analysis

\begin{tabular}{|c|c|c|c|c|c|c|}
\hline Model 1 & Rational appeal & $\mathrm{R}^{2}$ & $\mathrm{~F}$ & $\mathrm{Sig}$ & Beta & Sig \\
Online Branding Features & & .053 & 13.642 & .000 & .231 & .000 \\
\hline Model 2 & Rational appeal & .093 & 12.287 & .000 & .156 & .018 \\
Online Branding Features & Customer attitude & & & & .212 & .001 \\
\hline Model 3 & Rational appeal & .093 & 8.161 & .000 & .179 & .439 \\
Online Branding Features & Customer attitude & & & & .226 & .153 \\
& Rational appeal_Customer attitude & & & & -.032 & .918 \\
\hline
\end{tabular}

The second regression gives value of $\mathrm{R}^{2}$ as 0.093 which is too high. This model has an $\mathrm{F}$ value of 12.287 which is significant at 0.000 . Customer attitude has a beta value of .212 which is significant at 0.001 . And the independent variable has a beta value of .156 with a significance of $.018 \mathrm{p}<0.05$. This indicates 1 unit standard deviation change in customer attitude can cause .217 units change in online branding.

In the third regression (model 3) interaction term gives $\mathrm{R}^{2}$ value of 0.093 . The $\mathrm{F}$ value is again significant at $0.000 \mathrm{p}<0.05$. Beta value for the interaction term is -.032 , significance value of .918 so $\mathrm{p}>0.05$ and moderator has beta value of .226 with a significance value of .153 and $p>0.05$.

Table 3 considers online brand's website elements. The regression of rational appeal and online brand's website elements gives $\mathrm{R}^{2}$ of .079 . This model has $\mathrm{F}$ value of 20.665 which is 
significant at 0.000 which is less than 0.05 . The beta value of rational appeal is .280 which is statistically significant at .000 . So 1 unit change in rational appeal can cause .280 unit change in online branding.

Table 3. Regression analysis

\begin{tabular}{|c|c|c|c|c|c|c|}
\hline $\begin{array}{l}\text { Model } 1 \\
\text { Online brand's website elements }\end{array}$ & Rational appeal & $\begin{array}{l}\mathrm{R}^{2} \\
.079\end{array}$ & $\begin{array}{c}F \\
20.665\end{array}$ & $\begin{array}{l}\text { Sig } \\
.000\end{array}$ & $\begin{array}{r}\text { Beta } \\
.280\end{array}$ & $\begin{array}{l}\text { Sig } \\
.000\end{array}$ \\
\hline $\begin{array}{l}\text { Model } 2 \\
\text { Online brand's website elements }\end{array}$ & $\begin{array}{l}\text { Rational appeal } \\
\text { Customer attitude }\end{array}$ & .112 & 15.274 & .000 & $\begin{array}{l}.211 \\
.197\end{array}$ & $\begin{array}{l}.001 \\
.003\end{array}$ \\
\hline $\begin{array}{l}\text { Model } 3 \\
\text { Online brand's website elements }\end{array}$ & $\begin{array}{c}\text { Rational appeal } \\
\text { Customer attitude } \\
\text { Rational appeal__ Customer } \\
\text { attitude }\end{array}$ & .116 & 10.462 & .000 & $\begin{array}{l}.009 \\
.065 \\
.283\end{array}$ & $\begin{array}{l}.970 \\
.675 \\
.356\end{array}$ \\
\hline
\end{tabular}

Now in second model customer attitude gives $\mathrm{R}^{2}$ of .112 . The $\mathrm{F}$ value of this model is 15.274 and showing significance of .000 which is less than 0.05 so it is statistically significant. The beta value of rational appeal and customer attitude is .211 and .197 and giving significance of .001 and .003 respectively.

In the third model where the interaction term is added which gives $\mathrm{R}^{2}$ of .116 . The $\mathrm{F}$ value is 10.462 which is significant. Customer attitude as a moderator has beta value of .065 and shows the level of significance of .675 which is more than .05 so this is not statistically significant. The interaction term has a beta value of .283 , showing $p$ value of .356 . This value is more than .05 . So there is no moderation occurring.

Customer attitude is regressed against online branding to identify the relationship between the two variables. Table 4 shows that value of $\mathrm{R}^{2}$ is .071 . In other words $7.1 \%$ of change in online branding features is due to customer attitude.

Table 4. Regression analysis

\begin{tabular}{|l|l|c|c|c|c|c|}
\hline \multicolumn{2}{|l|}{ Regression Analysis } & $\mathrm{R}^{2}$ & $\mathrm{~F}$ & Sig & Beta & Sig \\
\hline Model & Customer attitude & .071 & 18.533 & .000 & .267 & .000 \\
\hline $\begin{array}{l}\text { Model } 1 \\
\text { Online branding features }\end{array}$ & & & & & \\
\hline
\end{tabular}

F value comes out to be 18.533 which is statistically significant at .000 . This proves the statistical significance of the model and the relationship between customer attitude and online branding features. Beta value of .267 is significant as it gives significance value of .000 which is less than the value of .05 .

Table 5 gives $\mathrm{R}^{2}$ value of .073 when customer attitude is regressed against online brand's website features. Customer attitude causes $7.3 \%$ change in online brand's website elements. 
Table 5. Regression analysis

\begin{tabular}{|l|c|c|c|c|c|c|}
\hline \multicolumn{2}{|l|}{ Regression Analysis } & $\mathrm{R}^{2}$ & $\mathrm{~F}$ & Sig & $\begin{array}{c}\text { Standardized } \\
\text { coefficients Beta }\end{array}$ & Sig \\
\hline $\begin{array}{l}\text { Model } \\
\text { Online brand's website elements }\end{array}$ & $\begin{array}{c}\text { Customer } \\
\text { attitude }\end{array}$ & .073 & 19.195 & .000 & .271 & .000 \\
\hline
\end{tabular}

F value in Table 5 is 19.195 which is significant at .000 . This shows statistical significance of the model and also shows that the relationship between customer attitude and online brand's website elements is significant. Beta value of .271 is significant at .000 . So this table also shows significant results for the relationship between customer attitude and online branding.

Customers were asked to mention the recent online purchases they made. The data obtained for this question is analyzed using a T-test. Considering online branding features and online brand's website elements there are 216 customers who purchased personal items online while 28 purchased gadgets from an online store.

Table 6. T-test

\begin{tabular}{|c|l|c|c|c|c|c|}
\hline \multicolumn{2}{|c|}{} & $\mathrm{df}$ & $\begin{array}{c}\text { Sig } \\
(2 \text {-tailed })\end{array}$ & $\begin{array}{c}\text { Mean } \\
\text { difference }\end{array}$ & Lower & Upper \\
\hline $\begin{array}{c}\text { Online branding } \\
\text { features }\end{array}$ & Equal variances assumed & 242 & .064 & .17667 & -.01017 & .36352 \\
\cline { 2 - 7 } Online brand's & Equal variances not assumed & 36.197 & .051 & .17667 & -.00077 & .35412 \\
\cline { 2 - 7 } website elements & Equal variances assumed & 242 & .158 & .11661 & -.04553 & .27875 \\
& Equaliances not assumed & 37.230 & .119 & .11661 & -.03141 & .26464 \\
\hline
\end{tabular}

Now for Table 6 in case of online branding features the significance comes out to be .051 . This indicates that the mean score among the two groups is not significantly different. The mean difference given is .17667. With the confidence interval of $95 \%$ the lower value is -.00077 and upper value is .35412 . So it indicates that there is $95 \%$ confidence that actual difference in the mean values for purchasing personal items and gadgets lie between -.00077 and .35412. This puts forward the conclusion that sometimes personal items will be purchased and sometimes gadgets would be purchased from the internet. So there is some difference between the purchase of personal items and gadgets as is evident from the significance value of .051 .

The significance value of online brand's website elements is .119 which is more than the level of significance of .05. The mean difference for online brand's website elements is .11661. Online brand's website elements have a lower value of -.03141 and an upper value of .26464 . There is $95 \%$ confidence that the actual difference among the mean values of personal items and gadgets lies between -.03141 and .26464. So with respect to online brand's website elements there is no significant difference between the purchase of personal items and gadgets. 
The demographic data revealed that there were $53.3 \%$ males and $46.7 \%$ females. $80.3 \%$ of the respondents were aged between 20 to 30 years. In terms of education $30.7 \%$ of the respondents had masters degree and $23.8 \%$ had MS degree. $82.4 \%$ accessed the internet from home. $75.4 \%$ of the respondents used the internet more than twice a day.

\section{Conclusion and Recommendation}

The purpose of this study is to identify relationship between rational advertisement appeal and online branding in Pakistan. Customer attitude plays the role of moderator in order to identify whether it moderates the relationship between rational advertisement appeals and online branding. The relationship between customer attitude and online branding is also taken into consideration. Further by considering the context of online branding it is researched whether significant differences exist between the product type or not.

Rational advertisement appeals effectively highlight the features and benefits of the products. These appeals are usually associated with complex products that require greater mental processing. Rational appeals are effective in terms of providing the information and facts through advertisements. Online brands are effective in getting the attention of the audience. They provide the audience with the required value, experience and interactivity that shapes their attitude and helps them in getting the required information through the online brand's website. There also exist some differences in the product type purchase on the internet. Some consumers prefer to purchase personal items from the internet while others go for gadgets.

Quantitative research design with a sample of 244 respondents is used. Data was collected from respondents who have done online shopping. So an online questionnaire was developed for this purpose. Data was analyzed using SPSS 22. Factor analysis, regression analysis and a T-test was performed in order to analyze relationship among the variables.

\subsection{Conclusion}

There is a significant relationship between rational advertisement appeals and online branding. Rational appeals which convey logic, educative information, low price and energy saving are effective and influence the brands presented on the web. Customer attitude did not moderate the relationship between rational advertisement appeal and online branding. Whereas there is significant relationship between customer attitude and online branding. Customer attitude has a positive influence on online brands. Product types considered while considering the online brands differed slightly in terms of customers making the purchase. As there are different product types available on the internet so there was some difference between the purchase of personal items and gadgets.

\subsection{Research Contribution}

This study makes an important contribution in the existing literature. Effect of rational advertisement appeals on online branding was not researched before. This study identified the relationship between rational advertisement appeal and online branding and also tested for the moderation effect of customer attitude. It is important to determine whether advertisement appeals work well in supporting online brands within Pakistan and this research shows that 
rational advertisement appeals are effective and have significant relationship with online branding. Customer attitude plays important role in online branding. These variables have not been researched in this context before. Therefore this study fulfills the gap and contributes well to the existing body of knowledge.

\subsection{Research Implications/ Recommendations}

This research also has important implications for the practitioners. First, while formulating advertisements in order to promote online brands, advertisers should use rational advertisement appeal by considering the product type and their ability to convey logic, educative information, low price and energy saving aspects. Second, special attention should be paid towards customer attitude while considering its impact on online brands. Third, personal items and gadgets should be categorized on internet so that consumers can purchase easily since there exist some differences between the purchases of two types of products.

\subsection{Directions for Future Research}

This study is not free from limitations. First the sample size was small so future research should be conducted with a larger sample size. Second $80 \%$ of the respondents comprising of the sample were between ages of 20 to 30 so data is not represented equally by all age groups. Future research should have equal representation of data from all age groups. Third this study is conducted in Pakistan and it cannot be generalized to other countries. So in future this research should be conducted in that specific country to be generalized. Fourth emotional advertisement appeal did not had a significant relationship with online branding. Future research should consider the impact of emotional advertisement appeals for the advertisement of online services. Fifth the present study considered the online purchase differences between two product types. Future research should consider other product types such as tangible, and intangible in order to identify how consumer behavior differs according to them. Sixth data is collected from one type of social media only that is Facebook. So future research should use other types of social media as well such as Twitter and LinkedIn.

\section{References}

Abzari, M., Ghassemi, R. A., \& Vosta, L. N. (2014). Analyzing the effect of social media on brand attitude and purchase intention: The case of Iran Khodro Company. Social and Behavioral Sciences, 143, 822-826.

Behboudi, M., Vazifehdoust, H., Najafi, K., \& Najafi, M. (2014). Using rational and emotional appeals in online advertisements for Muslim customers. Journal of Islamic Marketing, 5(1), 97-124. https://doi.org/10.1108/JIMA-07-2012-0039

Bergstrom, A. (2000). Cyberbranding: leveraging your brand on the internet. Strategy and Leadership, 28(4), 10-15. https://doi.org/10.1108/10878570010378645

Celebi, S. I. (2015). How do motive affect attitudes and behaviors toward internet advertising and facebook advertising. Computers in Human Behavior, 51, 312-324. https://doi.org/10.1016/j.chb.2015.05.011 
Cheng, F. F., Wu, C. S., \& Chen, Y. C. (2018). Creating customer loyalty in online brand communities. Computers in Human Behavior. https://doi.org/10.1016/j.chb.2018.10.018

Choo, H. J., Moon, H., Kim, H., \& Yoon, M. (2012). Luxury customer value. Journal of Fashion Marketing and Management, 16(1), 81-101. https://doi.org/10.1108/13612021211203041

Christmann, A., \& Aelst, S. V. (2006). Robust estimation of cronbach's alpha. Journal of Multivariate Analysis, 97, 1660-1674. https://doi.org/10.1016/j.jmva.2005.05.012

Christodoulides, G., Chernatony, L. D., Furrer, O., Shiu, E., \& Abimbola, T. (2006). Conceptualizing and measuring the brand equity of online brands. Journal of Marketing Management, 22(7-8), 799-825. https://doi.org/10.1362/026725706778612149

De Almeida, S. O., Scaraboto, D., dos Santos Fleck, J. P., \& Dalmoro, M. (2018). Seriously Engaged Consumers: Navigating Between Work and Play in Online Brand Communities. Journal of Interactive Marketing, 44, 29-42. https://doi.org/10.1016/j.intmar.2018.05.006

Fazal-e-Hasan, S. M., Ahmadi, H., Mortimer, G., Grimmer, M., \& Kelly, L. (2018). Examining the role of consumer hope in explaining the impact of perceived brand value on customer-brand relationship outcomes in an online retailing environment. Journal of Retailing and Consumer Services, 41, 101-111. https://doi.org/10.1016/j.jretconser.2017.12.004

Holbrook, M. B. (1978). Beyond attitude structure: Toward the informational determinants of attitude. Journal of Marketing Research, 15(4), 545-556. https://doi.org/10.2307/3150624

Hunt, S. D. (2018). The ethics of branding, customer-brand relationships, brand-equity strategy, and branding as a societal institution. Journal of Business Research. https://doi.org/10.1016/j.jbusres.2018.07.044

Internet world stats. (2015). http://www.internetworldstats.com/stats.htm

Jevons, C. (2005). Names, brands, branding: Beyond the signs, symbols, products and services. Journal of Product and Brand Management, 14(2), 117-118. https://doi.org/10.1108/10610420510592590

Kay, M. J. (2006). Strong brands and corporate brands. European Journal of Marketing, 40(7/8), 742-760. https://doi.org/10.1108/03090560610669973

Kim, H., \& Bonn, M. A. (2015). The moderating effects of overall and organic wine knowledge on consumer behavioral intention. Scandinavian Journal of Hospitality and Tourism. https://doi.org/10.1080/15022250.2015.1007083

Ko, H., Cho, C. H., \& Roberts, M. S. (2005). Internet uses and gratifications a structural equation model of interactive advertising. Journal of Advertising, 34(2), 57-70. https://doi.org/10.1080/00913367.2005.10639191

Kotler, P., \& Keller, K. L. (2006). Marketing management. Upper saddle river, New Jersey: Pearson prentice hall. 
Kotler, P., Armstrong, G., Sounders, J., \& Wong, V. (1999). Principles of marketing. New Jersey, USA: Prentice hall inc.

Lian, J. W., \& Lin, T. M. (2008). Effects of consumer characteristics on their acceptance of online shopping: comparisons among different product types. Computers in Human Behavior, 24, 48-65. https://doi.org/10.1016/j.chb.2007.01.002

Logan, K., Bright, L. F., \& Gangadharbatla, H. (2012). Facebook vs. television: Advertising value perceptions among females. Journal of Research in Interactive Marketing, 6(3), 164-179. https://doi.org/10.1108/17505931211274651

Lwin, M., \& Phau, I. (2013). Effective advertising appeals for websites of small boutique hotels. Journal of Research in Interactive Marketing, 7(1), 18-32. https://doi.org/10.1108/17505931311316725

Meinard, Y., \& Tsoukiàs, A. (2018). On the rationality of decision aiding processes. European Journal of Operational Research. https://doi.org/10.1016/j.ejor.2018.09.009

Miiguel, F. J. P., Peregrina, A. F. A., \& Pelaez, J. C. (2015). Influences of gender and product type on online purchasing. Journal of Business Research.

Mitchell, A. A., \& Olson, J. C. (1981). Are product attribute beliefs the only mediator of advertising effects on brand attribute? Journal of Marketing Research, 18(3), 318-332. https://doi.org/10.2307/3150973

Moon, H., \& Sprott, D. E. (2016). Ingredient branding for a luxury brand: The role of brand and product fit. Journal of Business Research, 69(12), 5768-5774. https://doi.org/10.1016/j.jbusres.2016.04.173

Nwankwo, B. E., Aboh, J. U., Obi, T. C., Agu, S. A., \& Agbor, N. S. (2013). Influence of advertisement appeals and personality on telecoms consumption practices in Nigeria. International Journal of Academic Research in Business and Social Sciences, 3(9). https://doi.org/10.6007/IJARBSS/v3-i9/205

Pang, J., Keh, H. T., \& Peng, S. (2009). Effects of advertising strategy on consumer-brand relationships: A brand love perspective. Frontiers of Business Research in China, 3(4), 599-620. https://doi.org/10.1007/s11782-009-0029-8

Puto, C. P., \& Wells, W. D. (1984). Informational and transformational advertising: The differential effects of time. Advances in Consumer Research, 11, 638-643.

Rowley, J. (2004). Online branding. Online Information Review, 28(2), 131-138. https://doi.org/10.1108/14684520410531637

Saadeghvaziri, F., Dehdashti, Z., \& Askarabad, M. R. K. (2013). Web advertising assessing beliefs, attitudes, purchase intension and behavioral responses. Journal of Economic and Administrative Sciences, 29(2), 99-112. https://doi.org/10.1108/JEAS-09-2013-0029

Scolari, C. (2008). Online brands: Branding, possible worlds, and interactive grammars. Semiotica, 169(1/4), 169-188. https://doi.org/10.1515/SEM.2008.030 
Sorce, P., Perotti, V., \& Widrick, S. (2005). Attitude and age differences in online buying. International Journal of Retail and Distribution Management, 33(2), 122-132. https://doi.org/10.1108/09590550510581458

Spears, N., \& Singh, S. N. (2004). Measuring attitude toward the brand and purchase intentions. Journal of Current Issues and Research in Advertising, 26(2), 53-66. https://doi.org/10.1080/10641734.2004.10505164

Tan, T. M., \& Rasiah, D. (2011). A review of online trust branding strategies of financial services industries in Malaysia and Australia. Advances in Management and Applied Economics, 1(1), 125-150.

Teo, T. S. H. (2002). Attitudes toward online shopping and the internet. Behavior and Information Technology, 21(4), 259-271. https://doi.org/10.1080/0144929021000018342

Urizza, M. A., \& Cebollada, J. (2012). Private labels and national brands across online and offline channels. Management Decision, 50(10), 1772-1789. https://doi.org/10.1108/00251741211279594

Verma, S. (2009). Do all advertising appeals influence consumer purchase decision: an exploratory study. Global Business Review, 10(1), 33-43. https://doi.org/10.1177/097215090801000102

Vijayasarathy, L. R. (2002). Product characteristics and internet shopping intentions. Internet Research: Electronic Networking Applications and Policy, 12(5), 411-426. https://doi.org/10.1108/10662240210447164

Wagner, T. F., Baccarella, C. V., \& Voigt, K. I. (2017). Framing social media communication: Investigating the effects of brand post appeals on user interaction. European Management Journal, 35(5), 606-616. https://doi.org/10.1016/j.emj.2017.05.002

Wang, W., Qiu, L., Kim, D., \& Benbasat, I. (2016). Effects of rational and social appeals of online recommendation agents on cognition-and affect-based trust. Decision Support Systems, 86, 48-60. https://doi.org/10.1016/j.dss.2016.03.007

Williams, C. (2007). Research methods. Journal of Business and Economic Research, 5(3). https://doi.org/10.19030/jber.v5i3.2532

Yoo, C., \& Maclnnis, D. (2005). The brand attitude formation process of emotional and informational ads. Journal of Business Research, 58, 1397-1406. https://doi.org/10.1016/j.jbusres.2005.03.011

Zhang, A. (2008). Examining product and process effects on consumer preferences for online and offline channels. Business Process Management, 14(1), 85-95. https://doi.org/10.1108/14637150810849427 


\section{Macrothink}

\section{Appendix}

\section{Appendix 1. Online Questionnaire}

Dear Sir/ Madam,

I am student of MS (Business Administration) at Institute of Banking \& Finance, Bahauddin Zakariya University, Multan. As a part of my M.Phil research I am conducting a survey to determine the "Effect of Rational and Emotional advertisement appeals on online branding in Pakistan". For the completion of my research, I need some information from you. I shall be highly thankful if you fill in the questionnaire and help me in completion of my research. Since the questionnaire is being used for academic purpose, the information collected will be kept strictly confidential.

\section{Section 1: Demographic Profile}

Gender
Male
Female

Age

$\square$ Under $20 \quad \square$ b/w 20 \& $30 \quad \square$ b/w $31 \& 40 \quad \square_{\text {b/w }} 41 \& 50$

$\square$ b/w $51 \& 60 \quad \square 61$ and above

Education
Undergraduate
Graduate
Masters
MS/M Phil
$\mathrm{PhD}$

Internet access source
$\square$ Home
Work
Educational institution
Internet cafe

Frequency of internet access

$\square$ More than twice a month

Once a week

More than twice a week

Once a day

$\square$ More than twice a day

\section{Section 2: Rational and Emotional Advertisement Appeals}

Rational appeal is a message containing facts and information

Emotional appeals are messages that try to stimulate positive or negative feelings to motivate a purchase. Kindly answer the following questions

\begin{tabular}{|c|c|c|c|c|c|}
\hline Statements & $\begin{array}{l}\text { Strongly } \\
\text { Agree } \\
1\end{array}$ & $\begin{array}{c}\text { Agree } \\
2\end{array}$ & $\begin{array}{c}\text { Neutral } \\
3\end{array}$ & $\begin{array}{c}\text { Disagree } \\
4\end{array}$ & $\begin{array}{c}\text { Strongly } \\
\text { Disagree } \\
5\end{array}$ \\
\hline $\begin{array}{l}\text { I am attracted to rational appeal which depicts } \\
\text { logic }\end{array}$ & 1 & 2 & 3 & 4 & 5 \\
\hline
\end{tabular}




\begin{tabular}{|c|c|c|c|c|c|}
\hline $\begin{array}{l}\text { I am attracted to rational appeal which depicts } \\
\text { educative information }\end{array}$ & 1 & 2 & 3 & 4 & 5 \\
\hline $\begin{array}{l}\text { I am attracted to rational appeal which depicts } \\
\text { energy saving }\end{array}$ & 1 & 2 & 3 & 4 & 5 \\
\hline $\begin{array}{l}\text { I am attracted to rational appeal which depicts } \\
\text { low price }\end{array}$ & 1 & 2 & 3 & 4 & 5 \\
\hline $\begin{array}{l}\text { I am attracted to emotional appeal which } \\
\text { depicts thrill }\end{array}$ & 1 & 2 & 3 & 4 & 5 \\
\hline $\begin{array}{l}\text { I am attracted to emotional appeal which } \\
\text { depicts affection }\end{array}$ & 1 & 2 & 3 & 4 & 5 \\
\hline $\begin{array}{l}\text { I am attracted to emotional appeal which } \\
\text { depicts pride }\end{array}$ & 1 & 2 & 3 & 4 & 5 \\
\hline $\begin{array}{l}\text { I am attracted to emotional appeal which } \\
\text { depicts humor }\end{array}$ & 1 & 2 & 3 & 4 & 5 \\
\hline $\begin{array}{l}\text { I am attracted to emotional appeal which } \\
\text { depicts fear }\end{array}$ & 1 & 2 & 3 & 4 & 5 \\
\hline $\begin{array}{l}\text { I am attracted to emotional appeal which } \\
\text { depicts sadness }\end{array}$ & 1 & 2 & 3 & 4 & 5 \\
\hline $\begin{array}{l}\text { I am attracted to emotional appeal which } \\
\text { depicts disapproval }\end{array}$ & 1 & 2 & 3 & 4 & 5 \\
\hline $\begin{array}{l}\text { I am attracted to emotional appeal which } \\
\text { depicts discomfort }\end{array}$ & 1 & 2 & 3 & 4 & 5 \\
\hline \multicolumn{6}{|c|}{ Section 3: Customer Attitude } \\
\hline Statements & $\begin{array}{l}\text { Strongly } \\
\text { Agree } \\
1 \\
\end{array}$ & $\begin{array}{c}\text { Agree } \\
2\end{array}$ & $\begin{array}{c}\text { Neutral } \\
3\end{array}$ & $\begin{array}{c}\text { Disagree } \\
4 \\
4\end{array}$ & $\begin{array}{c}\text { Strongly } \\
\text { Disagree } \\
5\end{array}$ \\
\hline Generally, I like ads that I see on the web & 1 & 2 & 3 & 4 & 5 \\
\hline $\begin{array}{l}\text { Generally, I want to buy products/services } \\
\text { advertised on the web }\end{array}$ & 1 & 2 & 3 & 4 & 5 \\
\hline $\begin{array}{l}\text { I like advertisements created by the sponsor } \\
\text { company of the product or brand }\end{array}$ & 1 & 2 & 3 & 4 & 5 \\
\hline $\begin{array}{l}\text { I like ad created by customers/fans of the } \\
\text { product or brand }\end{array}$ & 1 & 2 & 3 & 4 & 5 \\
\hline $\begin{array}{l}\text { I want to try products/services by seeing ad } \\
\text { created by the sponsor company }\end{array}$ & 1 & 2 & 3 & 4 & 5 \\
\hline $\begin{array}{l}\text { I want to try products/services when I see ad } \\
\text { created by customers/fans }\end{array}$ & 1 & 2 & 3 & 4 & 5 \\
\hline $\begin{array}{l}\text { I like companies' offers and price reductions } \\
\text { on the web }\end{array}$ & 1 & 2 & 3 & 4 & 5 \\
\hline
\end{tabular}




\section{Section 4: Online Branding}

What are the recent online purchases you made?

By keeping in view your recent online purchase please answer the following questions

\begin{tabular}{|l|c|c|c|c|c|}
\hline Statements & $\begin{array}{c}\text { Strongly } \\
\text { Agree } \\
1\end{array}$ & 2 & 3 & 4 & $\begin{array}{c}\text { Agree } \\
\text { Disagree } \\
5\end{array}$ \\
\hline $\begin{array}{l}\text { This online brand is dependable and } \\
\text { reliable }\end{array}$ & 1 & 2 & 3 & 4 & 5 \\
\hline $\begin{array}{l}\text { This online brand is ready and willing to } \\
\text { respond to customer needs }\end{array}$ & 1 & 2 & 3 & 4 & 5 \\
\hline $\begin{array}{l}\text { This online brand makes a claim or } \\
\text { promise about its products, it's probably } \\
\text { true }\end{array}$ & 1 & 2 & 3 & 4 & 5 \\
\hline $\begin{array}{l}\text { This online brand treats me like an } \\
\text { important and valuable customer }\end{array}$ & 1 & 2 & 3 & 4 & 5 \\
\hline $\begin{array}{l}\text { My experience on this online brands } \\
\text { website is exciting }\end{array}$ & 1 & 2 & 3 & 4 & 5 \\
\hline $\begin{array}{l}\text { I feel as though I really understand this } \\
\text { online brand }\end{array}$ & 1 & 2 & 3 & 4 & 5 \\
\hline This online brand is meaningful to me & 1 & 2 & 3 & 4 & 5 \\
\hline $\begin{array}{l}\text { I trust this online brand will not misuse } \\
\text { my personal information }\end{array}$ & 1 & 2 & 3 & 4 & 5 \\
\hline $\begin{array}{l}\text { This online brand's website enables me } \\
\text { to order products that are tailor-made } \\
\text { for me }\end{array}$ & 1 & 2 & 3 & 4 & 5 \\
\hline $\begin{array}{l}\text { This online brand's website has a good } \\
\text { balance between text and graphics }\end{array}$ & 1 & 2 & 3 & 4 & 5 \\
\hline $\begin{array}{l}\text { This online brand's website is pleasing } \\
\text { to the eye }\end{array}$ & 1 & 2 & 3 & 4 & 5 \\
\hline $\begin{array}{l}\text { While I was on this brand's website, I } \\
\text { could choose freely what I wanted to } \\
\text { see }\end{array}$ & 1 & 2 & 3 & 4 & 5 \\
\hline $\begin{array}{l}\text { Inquiries made on this online brand's } \\
\text { website are answered promptly }\end{array}$ & 1 & 2 & 3 & 4 & 5 \\
\hline $\begin{array}{l}\text { The product that came was described } \\
\text { accurately by online brand's website }\end{array}$ & 1 & 2 & 3 & 4 & 5 \\
\hline
\end{tabular}




\begin{tabular}{|l|l|l|l|l|l|}
\hline $\begin{array}{l}\text { Getting information from this online } \\
\text { brand's website is very fast }\end{array}$ & 1 & 2 & 3 & 4 & 5 \\
\hline $\begin{array}{l}\text { This online brand's website is easy to } \\
\text { use }\end{array}$ & 1 & 2 & 3 & 4 & 5 \\
\hline $\begin{array}{l}\text { I feel related to the type of people who } \\
\text { are customers of this online brand }\end{array}$ & 1 & 2 & 3 & 4 & 5 \\
\hline $\begin{array}{l}\text { I felt that I had a lot of control over my } \\
\text { visiting experiences at this online } \\
\text { brand's website }\end{array}$ & 1 & 2 & 3 & 4 & 5 \\
\hline $\begin{array}{l}\text { This online brand's website facilitates } \\
\text { two-way communication between the } \\
\text { visitors and the site }\end{array}$ & 1 & 2 & 3 & 4 & 5 \\
\hline $\begin{array}{l}\text { My experience on this online brand's } \\
\text { website is frustrating }\end{array}$ & 1 & 2 & 3 & 4 & 5 \\
\hline $\begin{array}{l}\text { The product was delivered by the time } \\
\text { promised by this online brand }\end{array}$ & 1 & 2 & 3 & 4 & 5 \\
\hline
\end{tabular}

\section{Copyright Disclaimer}

Copyright for this article is retained by the author(s), with first publication rights granted to the journal.

This is an open-access article distributed under the terms and conditions of the Creative Commons Attribution license (http://creativecommons.org/licenses/by/3.0/). 